\title{
Relationship between Holocene climate variations over southern Greenland and eastern Baffin Island and synoptic circulation pattern
}

\author{
B. Fréchette and A. de Vernal \\ GEOTOP, Université du Québec à Montréal, C. P. 8888, Succursale centre-ville, Montréal, Québec, H3C 3P8, Canada
}

Received: 20 February 2009 - Published in Clim. Past Discuss.: 10 March 2009

Revised: 18 June 2009 - Accepted: 25 June 2009 - Published: 14 July 2009

\begin{abstract}
Lake pollen records from southwest Greenland and eastern Baffin Island show strong regionalism in climate trends of the last 7000 cal years. July surface air temperature reconstructions from pollen indicate larger amplitude cooling in southwest Greenland $\left(>3.0^{\circ} \mathrm{C}\right)$ than in eastern Baffin Island $\left(<1.0^{\circ} \mathrm{C}\right)$. This west-east gradient in climate change is consistent with August sea-surface temperature reconstructions from dinocyst records that indicate decreasing temperature and/or strength of the North Atlantic Current to the east during the Holocene while the eastern Canadian margins under the Labrador Current influence display slight warming. Complementary to air and sea-surface temperature records, the lake pollen data led to reconstruct increased cloudiness in southern Greenland, which points to increasing cyclonic activity since 7000 cal years BP west of Greenland. Together, the terrestrial and marine records of the northwest North Atlantic therefore suggest a shift from a dominant NAO+ during the early-mid Holocene to dominant NAO- in the late Holocene.
\end{abstract}

\section{Introduction}

Present-day climate conditions across the subpolar North Atlantic are by no means uniform or zonal, and regional scale differences need to be taken into account in paleoclimate studies and for climate modelling (e.g. Wohlfahrt et al., 2004; Renssen et al., 2005). Over the past few years, paleoecological studies at high latitudes of the Northern Hemisphere have reported a strong regionalism in both terrestrial climate and sea-surface conditions of the oceans (Marchal et al., 2002; Kaufman et al., 2004; Moros et al., 2004; de Vernal and Hillaire-Marcel, 2006). In particular, the northern North At-

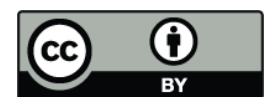

Correspondence to: B. Fréchette (bianca.frechette@internet.uqam.ca) lantic has been marked by much larger cooling in surface water to the east than to the west from the early to late Holocene (Marchal et al., 2002; Moros et al., 2004; Andersen et al., 2004). In addition, variations in sea-surface salinity and sea-ice cover along the continental margin off Canada and strengthening of deep water formation in the Labrador Sea since the early Holocene suggest important changes in ocean thermohaline conditions and circulation pattern (de Vernal and Hillaire-Marcel, 2006). However, our understanding of the climate dynamics at high latitudes remains fragmentary because most paleoclimate studies report on surface ocean or air temperatures with little indication on seasonality or other climate parameters such as precipitation, wind patterns, moisture and cloud cover. The present study addresses the question of linkages between terrestrial climate and ocean records in the subpolar North Atlantic during the Holocene, with special attention paid to the climate parameters such as cloudiness in addition to surface air and ocean temperature. Our study aims at interpretations in terms of large-scale circulation pattern involving notably the North Atlantic Oscillation (NAO) (Hurrell, 1995), which controls the strength and direction of winds blowing across the North Atlantic Ocean and thus the circulation of surface water in the ocean.

We use palynological data from marine and lacustrine cores collected in the northwest North Atlantic and adjacent lands (east Baffin Island and southwest Greenland) to derive climate records spanning about 8000 cal years (Fig. 1). The coring sites are located in the trajectory of surface ocean currents that play a major role in northward heat fluxes, the North Atlantic Current (NAC) and its westward branch making the West Greenland Current (WGC) and southward Arctic water flow through the Baffin Land Current (BLC) and the Labrador Current (LC). The core sites are well located to document synoptic scale changes, notably with regard to the trajectory of North Atlantic storm tracks in the Labrador Sea, which ends in south Greenland (Chen et al., 1997; Tsukernik et al., 2007). They are also suitably located to document

Published by Copernicus Publications on behalf of the European Geosciences Union. 


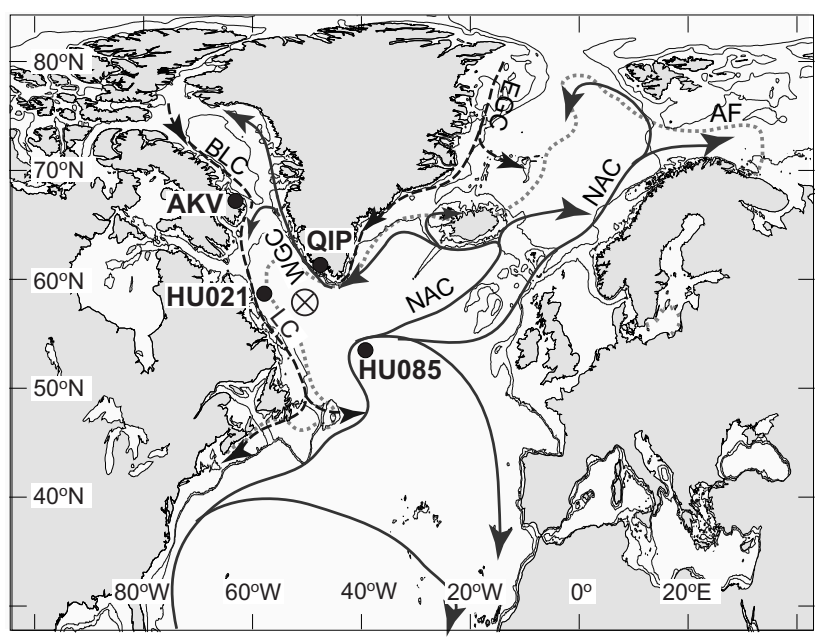

Fig. 1. Map of the northern North Atlantic showing the location of the study sites. The isolines correspond to the $200 \mathrm{~m}$ and $1000 \mathrm{~m}$ isobaths. The arrows illustrate schematically the surface circulation of the North Atlantic. The dark grey arrows correspond to the poleward flow of the North Atlantic Current (NAC), and its western branch, associated with the West Greenland Current (WGC). The dashed black arrows correspond to southward flow of Arctic waters through the East Greenland Current (EGC), the Baffin Land Current (BLC) and the Labrador Current (LC). Circle cross corresponds to the center of deep Labrador Sea Water (LSW) formation. The dashed grey line corresponds to the maximum extent of seaice cover in winter. Study sites: Akvaqiak Lake (AKV), Qipisarqo Lake (QIP), Core HU021 (HU021), Core HU085 (HU085).

NAO. Positive NAO is characterized by reduced strength and frequency of cyclonic activity in the Labrador Sea (Serreze et al., 1997), which results in overall cloudiness decrease over much of the North Atlantic, west of Greenland, whereas negative NAO rather results in cloudiness increase (Previdi and Veron, 2007).

\section{Study area}

The studied lakes are located on eastern Baffin Island (Akvaqiak Lake [AKV]; $66^{\circ} 47^{\prime} \mathrm{N}, 63^{\circ} 57^{\prime} \mathrm{W} ; 17 \mathrm{~m}$ a.s.1.) and in southwest Greenland (Qipisarqo Lake [QIP]; $61^{\circ} 00^{\prime} \mathrm{N}$, $47^{\circ} 45^{\prime} \mathrm{W}$; $7 \mathrm{~m}$ a.s.l.) (Fig 1). Qipisarqo Lake measures about $600 \times 900 \mathrm{~m}$ (see Fig. 1b in Kaplan et al., 2002) and Akvaqiak Lake is slightly smaller an roughly oval in shape (about $390 \times 600 \mathrm{~m}$ ). The climate conditions at the two sites are contrasted, especially in winter. The present-day July and January air temperatures average respectively $4.9^{\circ} \mathrm{C}$ and $-24.1^{\circ} \mathrm{C}$ on eastern Baffin Island and $8.4^{\circ} \mathrm{C}$ and $-6.2^{\circ} \mathrm{C}$ in southwest Greenland (Cappelen et al., 2001; Environment Canada, 2004). The milder climate of southern Greenland is related to the influence of the WGC, whereas the outflow of Arctic waters through the BLC results in cold winter conditions on eastern Baffin Island. Sunshine (inversely propor- tional to cloud cover) during the growing season of the vegetation (June-September) averages $37 \%$ and $32 \%$ respectively on eastern Baffin Island and in southwest Greenland (New et al., 2002; Whitmore et al., 2005). Sunshine is lower in southwest Greenland than eastern Baffin Island notably because south Greenland is located along a primary North Atlantic cyclone track, which is enhanced by the proximity of relatively warm ocean surface current (WGC) to the Greenland ice sheet (Chen et al., 1997; Tsukernik et al., 2007). Despite contrasting climate, the local vegetation of these sites is comparable. Vegetation is moderately lush shrub tundra dominated by shrub birch (Betula) and heaths (Ericales). Shrub alder (Alnus) is absent from the Baffin Island vegetation but is regionally common in southwest Greenland $\left(61^{\circ}-\right.$ $66^{\circ} \mathrm{N}$ ) (e.g. Fredskild, 1996). The modern pollen flux is of the order of 500 grains $/ \mathrm{cm}^{2} / \mathrm{yr}$ at Qipisarqo and of the order of 90 grains $/ \mathrm{cm}^{2} / \mathrm{yr}$ at Akvaqiak. Pollen assemblages are dominated by Betula but Alnus and herb pollen grains record higher percentages at Qipisarqo.

The studied marine cores were collected on the continental slope of the Canadian margin, at the vicinity of the center of Labrador Sea Water (LSW) formation (Core HU84-030-021TWC [HU021]; 58 $22.06^{\prime} \mathrm{N}, 57^{\circ} 30.42^{\prime} \mathrm{W}$; water depth $=2853 \mathrm{~m}$ ), and in the area of the Charlie Gibbs Fracture Zone in the central part of the North Atlantic (Core HU-91-045-085TWC [HU085]; 5358.51' N, 38 38.25' W; water depth=3603 m) (Fig. 1). The core HU021 is located close to a front between the LC and the WGC. Modern mean sea-surface temperature (SST) and salinity (SSS) are $6.7^{\circ} \mathrm{C}$ and 34.3 in summer and $3.4^{\circ} \mathrm{C}$ and 34.8 in winter, respectively, and sea-ice cover develops for about 2 months per year (2.0 1.05$)$ (NODC, 2001). The core HU085 is along the axis of the warm NAC, where SSTs are $10.3^{\circ} \mathrm{C}$ and $5.3^{\circ} \mathrm{C}$ in summer and winter respectively and where SSS ranges 34.5 to 34.8 (NODC, 2001).

\section{Methods}

\subsection{Lacustrine sediment cores chronology and pollen analysis}

Akvaqiak (98BIR-02, 98BIR-G01) and Qipisarqo (98QIP02, 98QIP-G01) lake cores were collected in May 1998 from the frozen lake surface. Qipisarqo Lake sedimentology is thoroughly discussed in Kaplan et al. (2002). At the two lakes, piston and gravity (Glew) cores were used for the establishment of composite records, in which the Glew cores provide the upper part of the sedimentary sequences. The chronology of the Akavqiak Lake record is based on seven accelerator mass spectrometry (AMS) ${ }^{14} \mathrm{C}$ dates on bryophyte macrofossils and humic acid extracts (Table 1). The chronology of the Qipisarqo Lake record is based on six AMS- ${ }^{14} \mathrm{C}$ dates on bryophyte macrofossils and humic acid extracts (see Kaplan et al., 2002) (Table 1). Paired 
Table 1. AMS ${ }^{14} \mathrm{C}$ dates from (a) Akvaqiak and (b) Qipisarqo lake cores used for developing the age-depth model.

\begin{tabular}{|c|c|c|c|c|c|c|c|}
\hline $\begin{array}{l}\text { Raw depth } \\
\quad(\mathrm{cm})\end{array}$ & $\begin{array}{l}\text { Composite depth } \\
(\mathrm{cm})^{\mathrm{a}}\end{array}$ & Laboratory No. & Material & $\begin{array}{l}\text { AMS } 14 \mathrm{C} \text { date } \\
(\mathrm{yr} \mathrm{BP})\end{array}$ & $\begin{array}{l}\text { Corrected date } \\
\qquad(\mathrm{yr} \mathrm{BP})^{\mathrm{b}}\end{array}$ & $\begin{array}{l}\text { Calibrated date } \\
\qquad(\mathrm{yr} \mathrm{BP})^{\mathrm{c}}\end{array}$ & $\begin{array}{c}\text { Range of solution } \\
95.4 \%(1 \sigma)\end{array}$ \\
\hline \multicolumn{8}{|c|}{ a) Akvaqiak Lake (piston core: 98BIR-02) } \\
\hline 8.5 & 11.5 & NSRL-11345 & Macroflora & $1000 \pm 50$ & - & 933 & $902-963$ \\
\hline 8.5 & 11.5 & NSRL-11346 & Humic acids & $1700 \pm 45$ & - & - & - \\
\hline 20.5 & 23.5 & NSRL-10621 & Humic acids & $2510 \pm 45$ & 1973 & 1915 & $1879-1951$ \\
\hline 28.5 & 31.5 & NSRL-11347 & Macroflora & $2270 \pm 60$ & - & 2211 & $2177-2245$ \\
\hline 28.5 & 31.5 & NSRL-11348 & Humic acids & $2840 \pm 55$ & - & - & - \\
\hline 40.5 & 43.5 & NSRL-10622 & Humic acids & $4290 \pm 50$ & 3753 & 4117 & $4076-4158$ \\
\hline 60.5 & 63.5 & NSRL-10623 & Humic acids & $6810 \pm 55$ & 6273 & 7214 & $7158-7270$ \\
\hline 80.0 & 83.0 & NSRL-10624 & Humic acids & $7670 \pm 60$ & - & - & - \\
\hline 80.0 & 83.0 & NSRL-10176 & Macroflora & $7330 \pm 95$ & 7330 & 8113 & $8020-8205$ \\
\hline 139.5 & 142.5 & NSRL-10139 & Macroflora & $8560 \pm 100$ & 8560 & 9550 & $9466-9634$ \\
\hline \multicolumn{8}{|c|}{ b) Qipisarqo Lake (piston core: 98QIP-02) } \\
\hline 20.0 & 22.5 & CURL-4475 & Humic acids & $1240 \pm 35$ & 1010 & 937 & $910-964$ \\
\hline 23.0 & 25.5 & CURL-3036 & Humic acids & $530 \pm 40$ & 300 & 394 & $357-431$ \\
\hline 40.0 & 42.5 & CURL-4486 & Humic acids & $1330 \pm 40$ & 1100 & 989 & $963-1014$ \\
\hline 60.0 & 62.5 & CURL-4476 & Humic acids & $2570 \pm 35$ & 2340 & 2346 & $2327-2365$ \\
\hline 86.5 & 89.0 & CURL-3037 & Humic acids & $3970 \pm 40$ & 3740 & 4114 & $4076-4151$ \\
\hline 136.0 & 138.5 & CURL-4487 & Humic acids & $5840 \pm 60$ & 5610 & 6377 & $6317-6437$ \\
\hline 136.0 & 138.5 & CURL-4488 & Macroflora & $5610 \pm 60$ & 5610 & 6377 & $6317-6437$ \\
\hline 187.5 & 190.0 & CURL-3038 & Humic acids & $8400 \pm 40$ & 8170 & 9079 & 9023-9135 \\
\hline 264.0 & 266.5 & CURL-4914 & Macroflora & $8560 \pm 50$ & 8560 & 9524 & 9498-9549 \\
\hline
\end{tabular}

a Depth added to correct for offset between piston and gravity (Glew) core depths.

$\mathrm{b}$ Years subtracted from humic acid ages to correct for offset measured between paired macrofossil and humic acid dates.

${ }^{c}$ Calibration using the CALIB program (version 5.0.2) (Stuiver and Reimer, 1993) updated with the Intcal04c14 (Reimer et al., 2004).

macrofossil and humic acid dates have been obtained at three levels in the Akvaqiak Lake core and one level in the Qipisarqo Lake core, producing humic acid ages that are older than adjacent macrofossils. This has led to age correction of 537 and 230 years for humid acid dates in Akvaqiak and Qipisarqo lakes, respectively. All corrected (humic acid) and uncorrected (bryophyte) dates have been calibrated to calendar years using the CALIB program (version 5.0.2) (Stuiver and Reimer, 1993) updated with the Intcal04c14 dataset (Reimer et al., 2004). Age models were then derived from smoothed linear interpolation between calibrated ages (Fig. 2). For the last 8000 cal years, sediment accumulation rates average $11.35 \pm 4.41 \mathrm{~cm} / \mathrm{ka}$ at Akavaqiak Lake and $26.77 \pm 16.84 \mathrm{~cm} / \mathrm{ka}$ at Qipisarqo Lake.

Standard pollen preparation techniques, including dispersion with $\mathrm{KOH}$, digestion with $\mathrm{HF}$ and $\mathrm{HCl}$, and acetolysis (Faegri and Iversen, 1975), were applied to 1.0 or $2.0 \mathrm{~cm}^{3}$ samples of fresh (wet) sediment. Pollen and spores were identified using the taxonomic keys of Richard (1970), McAndrews et al. (1973) and Moore et al. (1991), as well as reference to modern collection archived at the Laboratoire Jacques-Rousseau, Université de Montréal. Palynological analyses performed at 3 to $5 \mathrm{~cm}$ interval yield a centennial resolution, which permits to identify long term trend. For consistency, the pollen sum used for computing relative frequencies from the fossil assemblages includes only the 39 pollen types contained in the modern database (cf. Table 1 in Fréchette et al., 2008a). Spores from pteridophytes, bryophytes and aquatic plants were excluded. The pollen sums average $555 \pm 48$ grains in samples from Akvaqiak Lake and $516 \pm 44$ grains in samples from Qipisarqo Lake.

\subsection{Marine sediment cores chronology and dinocyst analysis}

Cores HU021 and HU085 were collected during expeditions of the CSS-Hudson. The chronology was established on the basis of AMS ${ }^{14} \mathrm{C}$ dates on planktic foraminifera. For core HU021 three dates are available and for core HU085 two dates are available. The conventional ${ }^{14} \mathrm{C}$ ages have been calibrated into calendar years using the CALIB Rev 5.0.1 program (Stuiver and Reimer, 1993) and the marine calibration dataset (Marine04.14C) of Hughen et al. (2004). The marine calibration was made with a global ocean reservoir correction of 400 years, but no further correction of reservoir age (delta $R$ ) was applied to account for local effects. The age models were established from linear interpolation between calibrated ages. For the last 8000 cal years, sediment accumulation rates average $17.6 \mathrm{~cm} / \mathrm{ka}$ in core HU021 and $6.2 \mathrm{~cm} / \mathrm{ka}$ in core HU085. 

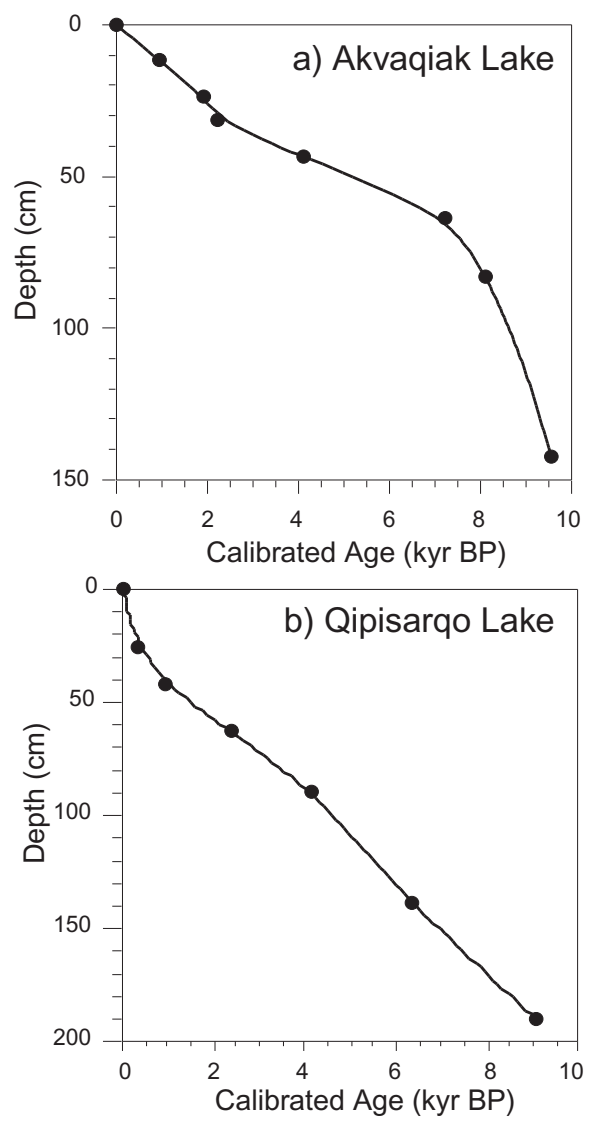

Fig. 2. Age-depth curves for the Akvaqiak (a) and Qipisarqo (b) lake composite sediment cores. Age-depth models used for Akvaqiak and Qipisarqo lake sediments are a smoothed linear interpolation between the available calibrated radiocarbon ages.

Palynological preparation for the analyses of dinocysts were made following standardized laboratory procedure that include sieving at $10 \mu \mathrm{m}$ to eliminate fine silt and clays, in addition to repeated $\mathrm{HCl}(10 \%)$ and $\mathrm{HF}(52 \%)$ treatments to dissolve carbonate and silica particles. No oxidation treatment was done. Palynological analyses performed at 1 to $2 \mathrm{~cm}$ interval yield a centennial resolution. For consistency, the dinocyst sum used for computing relative frequencies from the fossil assemblages includes only the 60 dinocyst taxa of the modern database (cf. Table 1 in de Vernal et al., 2005 ). The sums average $345 \pm 70$ cysts in samples from core HU021, and 256 \pm 87 cysts in samples from core HU085.

\subsection{Principal component analysis}

Detrended correspondence analysis (DCA) was first used to estimate the compositional gradient lenghts along the first few DCA axes in the lacustrine and marine records (Gauch, 1982; ter Braak and Prentice, 1988; Birks, 1995). For DCA calculations we used the pollen types and the dinocysts selected for the quantitative climate and hydrographic recon- structions. Among the 39 pollen types, 25 were present at Akvaqiak Lake and 31 at Qipisarqo Lake. Among the 60 dinocyst taxa, 25 were recorded in core HU021 and 21 in core HU085. The length of gradient of DCA axis 1 is 0.87 and 1.01 SD (standard deviation) units for Akvaqiak and Qipisarqo lakes, respectively, and 1.09 and $1.41 \mathrm{SD}$ units for cores HU021 and HU085, respectively, which indicates linear responses of both pollen and dinocysts to the underlying environmental gradient. Therefore, linear ordination (Principal Component Analysis) was applied. Principal Component Analysis (PCA) was used to detect the major gradient among the fossil pollen and dinocyst spectra. Because the variables are dimensionally homogeneous, a dispersion (variance/covariance) matrix was used (Birks, 1995; Legendre and Legendre, 1998). The number of pollen and dinocysts was lowered. We selected taxa with a value greater-than or equal to $1 \%$ in at least one sample and created a collective category among the pollen types (Picea + Pinus). This selection resulted in 10 pollen types for Akvaqiak Lake, 17 pollen types for Qipisarqo Lake, 15 dinocyst types for core HU021 and 17 dinocyst types for core HU085. For PCA, as for the quantitative climate and hydrographic reconstructions, the relative frequencies (in percent) of the pollen types were square-root transformed and the relative frequencies (in per mil) of dinocysts were logarithmic transformed. These transformations were done in order to optimize the signal-to-noise ratio and stabilize the variances. DCA was implemented with CANOCO version 4.0 (ter Braak and Šmilauer, 1998) with rare taxa not down-weighted. PCA calculations were performed using the computer program Progiciel R (version 4) (Legendre and Legendre, 1998). Informations on PCA results (first three eigenvalues, \% variance and loadings) are given on Supplementary Tables 1 and 2 (http://www. clim-past.net/5/347/2009/cp-5-347-2009-supplement.pdf).

\subsection{Continental climate reconstruction}

Continental climate was reconstructed using the Modern Analogue Technique (MAT) and a modern database of 828 sites from lakes of the Boreal, Subarctic and Arctic biomes of North America (north of $50^{\circ} \mathrm{N}$ ) and Greenland (Whitmore et al., 2005; Fréchette et al., 2008a). The surface air temperature (SAT), sunshine $(\mathrm{S})$ and precipitation $(\mathrm{P})$ were calculated from the Climatic Research Unit (CRU) gridded climatology using 1961-1990 climatological averages (New et al., 2002) and interpolated to the 828 pollen sites via lapse-rate collected bilinear interpolation. Whitmore et al. (2005) describe in full the method used to estimate modern climate. The gridded sunshine data provided by New et al. (2002) are expressed as percent of possible bright sunshine and were derived from sunshine averages at given stations or from conversion of cloud cover to sunshine. Modern climate parameters at Akvaqiak and Qipisarqo lakes were estimated in the same way. 
The pollen data include the 39 most common vascular taxa (18 woody plants and 21 herbs). The reconstructions based on MAT followed the procedure described in detail by Fréchette et al. (2008a). Similarity between fossil and modern pollen assemblages is based on the squared chord distance (SCD) dissimilarity metric (Birks, 1977; Prentice, 1980; Overpeck et al., 1985; Gavin et al., 2003), which is an euclidean distance calculated on the square-root transformed pollen types abundances expressed in percent. Values of SCD vary between zero and 200, with larger values indicating larger dissimilarity. The adopted SCD threshold for the present study is 26 . The climate estimates are calculated from the 5 best modern analogues.

Reconstructions of the July (warmest month) SAT and growing season (June-September = JJAS) sunshine were performed with the 3Pbase software (Guiot and Goeury, 1996). The accuracy of the approach (RMSE) is estimated to $\pm 1.4^{\circ} \mathrm{C}(r=0.92)$ for July SAT and $\pm 2.1 \%(r=0.87)$ for JJAS sunshine. It is of note that the errors are close to the squared root generalized cross validation (RTGCV), which provides an estimate of the mean predictive error (and hence power) of the fitted surface. At the scale of North America and Greenland $\left(20^{\circ}-85^{\circ} \mathrm{N}, 20^{\circ}-180^{\circ} \mathrm{W}\right)$, the RTGVC of July SAT is of $0.7^{\circ} \mathrm{C}$ and the RTGVC of summer sunshine is $4.5 \%$ (New et al., 1999, 2002). The accuracy of the interpolated monthly sunshine at high northern latitudes is influenced by the effect of low sun angles on the amount of bright sunshine recorded (New et al., 1999). Therefore, it is important to look at the station networks and cross-validation statistics for assessing the accuracy of the interpolation in the study region (New et al., 2002). At Akvaqiak and Qipisarqo lakes, July SAT is $6.2 \pm 1.0^{\circ} \mathrm{C}$ and $9.0 \pm 1.1^{\circ} \mathrm{C}$ respectively (Cappelen et al., 2001; Environment Canada, 2004), and JJAS sunshine is $39.6 \pm 5.8 \%$ and $33.2 \pm 1.9 \%$ respectively (New et al., 2002; Whitmore et al., 2005).

Redundancy Analysis (RDA) was used to estimate long term trends in winter SAT and annual precipitation. RDA ordination of the Arctic reference sites $(n=256,35$ pollen types, 4 climate variables: July and January SAT, annual precipitation, JJAS sunshine) demonstrates that the first RDA axis $\left(\lambda_{1}=0.184 ; 18.4 \%\right.$ of the total variance in the pollen data alone, and $62.5 \%$ of variance in the weighted-averages of the pollen taxa constrained to climate variables) positively correlates with January SAT $(r=0.79)$ and annual precipitation ( $r=0.63$ ) (cf., Fig. 5a). In the Arctic, these two climate parameters are strongly correlated $(r=0.86)$. Fossil pollen assemblages of Akvaqiak and Qipisarqo lakes were projected passively onto the ordination space, without influencing the RDA analysis in any other way. Therefore, the scores of Akavaqik and Qipisarqo spectra projected on RDA axis 1 of the Arctic-site modern assemblages allow semiquantitative estimates of January SAT. For RDA ordination the frequencies of the 35 pollen types were square-root transformed and rare taxa were not down-weighted. RDA was performed with CANOCO version 4.0 (ter Braak and
Šmilauer, 1998). Informations on RDA results (first three eigenvalues, \% variance and loadings) and correlation matrix between the 4 climate variables are given in Supplementary Tables 3 and 4 (http://www.clim-past.net/5/347/2009/ cp-5-347-2009-supplement.pdf).

\subsection{Hydrographic reconstruction}

Quantitative reconstruction of past sea-surface conditions is based on MAT applied to dinocyst assemblages. The reference database includes 60 taxa and 1054 reference sites from mid- to high latitude North Atlantic, North Pacific and Arctic oceans, and adjacent sub-polar seas (de Vernal and Hillaire-Marcel, 2006). The dissimilarity metric used is the euclidean distance calculated on neperian logarithmic transformed dinocysts abundance, expressed in per mil (de Vernal et al., 2001, 2005). Unlike the SCD used with the pollen database, the dissimilarity metric used with the dinocyst database has no upper limit. The adopted dissimilarity threshold for the present study is 74. The hydrographic values were estimated from the 5 best modern analogues. Reconstruction of the August (warmest month) sea-surface temperature (SST) was performed with the 3Pbase software (Guiot and Goeury, 1996). The error of prediction (RMSE) for August SST is estimated to $\pm 1.7^{\circ} \mathrm{C}$. It is of note that this error is close to the actual standard deviation around the mean for the summer temperature, which averages $\pm 1.6^{\circ} \mathrm{C}$ in the modern hydrographical database (NODC, 2001). Relatively close analogues for dinocyst assemblages exist in the modern database, with distances lower than 44 and 78 for cores HU021 and HU085, respectively. At sites HU021 and HU085, August SST is $6.7 \pm 0.9^{\circ} \mathrm{C}$ and $10.6 \pm 0.8^{\circ} \mathrm{C}$ respectively (NODC, 2001).

\section{Results}

\subsection{Lacustrine sediment cores}

The diagram of pollen assemblages of Akvaqiak and Qipisarqo lakes is given in Supplementary Fig. 1 (http://www. clim-past.net/5/347/2009/cp-5-347-2009-supplement.pdf).

The mid to late Holocene pollen influxes are of the order of 450 grains $/ \mathrm{cm}^{2} / \mathrm{yr}$ at Qipisarqo and $150 \mathrm{grains} / \mathrm{cm}^{2} / \mathrm{yr}$ at Akvaqiak. At both sites, the mid-late Holocene pollen assemblages are dominated by Betula and Ericales and are characterized by increasing abundances of Betula throughout the late Holocene. However, discrepancies exist regarding Alnus and pollen grains of coniferous trees (Picea and Pinus). These taxa are best represented at Qipisarqo Lake and the coniferous trees taxa are related to long-distance transport (e.g. Rousseau et al., 2008). The present local vegetation of these sites is comparable and the similarity is well expressed in their respective modern pollen assemblages. The SCD between the uppermost pollen assemblage of Akvaqiak and Qipisarqo lacustrine sequences is 14 (or 


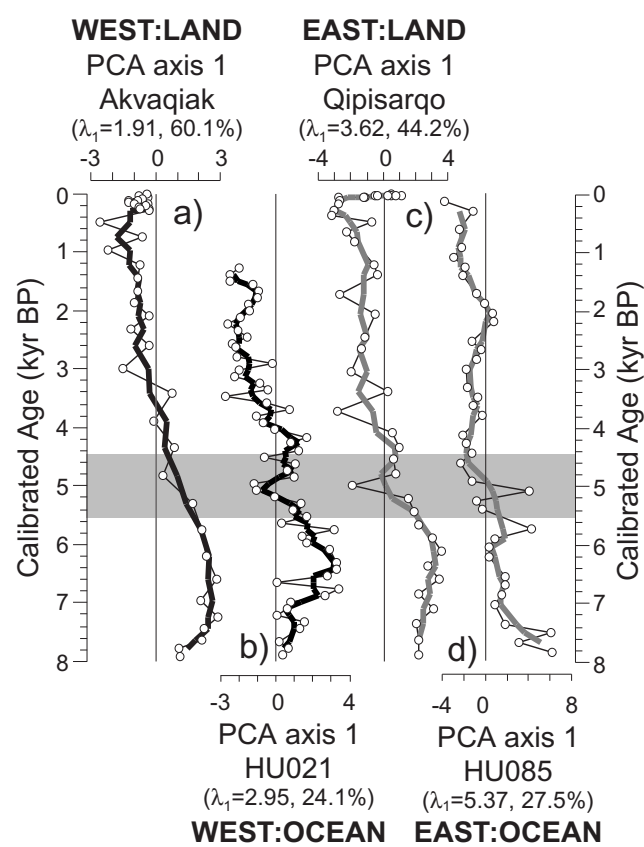

Fig. 3. Result of Principal Component Analysis (PCA). Stratigraphic plot of PCA axis 1 sample scores of (a) Akvaqiak Lake, (b) core HU021, (c) Qipisarqo Lake, (d) core HU085. The thick grey and thick black lines correspond to 3-point moving averages. The first eigenvalue $\left(\lambda_{1}\right)$ and percentage of variance are given for each sequence. WEST: western sector of northwest North Atlantic. EAST: eastern sector of northwest North Atlantic. The shaded horizontal zone marks the mid-late Holocene transition, which occurred at ca. 5000 cal year BP. Information on PCA summary and loadings are given on Supplementary Tables 1 and 2 (http://www.clim-past. net/5/347/2009/cp-5-347-2009-supplement.pdf).

$0.14)$, which indicates that they are indeed very similar to each other (cf. Overpeck et al., 1985; Anderson et al., 1989).

PCA performed on pollen assemblages show strong linear trends since 8000 cal years BP (Fig. 3a, c). The first eigenvalue $\left(\lambda_{1}\right)$ of the eastern site (Qipisarqo) is two times higher than that of western site (Akvaqiak), which indicates much higher amplitude changes in pollen assemblages in southwest Greenland than in eastern Baffin Island. At both sites, low PCA axis 1 sample scores are driven by Betula and Ericales, two erect dwarf shrubs, whereas high PCA axis 1 sample scores are driven by Cyperaceae at Akvaqiak and Alnus at Qipisarqo (Supplementary Tables 2a, b, http://www.clim-past. net/5/347/2009/cp-5-347-2009-supplement.pdf). At Akvaqiak and Qipisarqo, there is a pronounced change at about 5000 cal years BP. The change is gradual at Akvaqiak, whereas it appears more abrupt at Qipisarqo.

Close analogues for the fossil pollen assemblages exist in the modern database, with SCD values lower than 11 and 18 for Akavqiak and Qipisarqo lakes, respectively. At both sites, July SAT was maximum before 5000 cal years BP.
However, the subsequent cooling trend is more pronounced at the eastern site (Qipisarqo) than at the western site (Akvaqiak). From 7000 cal years BP to present, July SAT decreased by $0.5^{\circ} \mathrm{C} / \mathrm{ka}$ at Qipisarqo and by $0.1^{\circ} \mathrm{C} / \mathrm{ka}$ at $\mathrm{Ak}-$ vaqiak (Fig. 4a, b). Conversely, contrasting trends in the mid-late Holocene growing season sunshine are observed. From 7000 cal years BP to present, growing season sunshine increased at Akavaqiak $(+0.6 \% / \mathrm{ka})$, whereas it decreased at Qipisarqo (-0.8\%/ka) (Fig. 4c, d).

RDA performed on pollen assemblages show increasing trend since 8000 cal years BP (Fig. 5b, c). The first RDA axis is positively correlated with January SAT and annual precipitation (Fig. 5a). This increasing trend can thus likely records a slight winter warming and higher precipitation. Betula has the highest species score on the first RDA axis on Arctic reference sites (Supplementary Table 3, http://www. clim-past.net/5/347/2009/cp-5-347-2009-supplement.pdf) and in both lake sediment cores, there is an increase in Betula frequencies throughout the late Holocene (Supplementary Fig. 1, http://www.clim-past.net/5/347/2009/ cp-5-347-2009-supplement.pdf). Warm winter and thick snow cover are likely critical to the survival of Betula (cf. Fredskild, 1991).

\subsection{Marine sediment cores}

The diagram of dinocyst assemblages of cores HU021 and HU085 is given in Supplementary Fig. 2 (http://www. clim-past.net/5/347/2009/cp-5-347-2009-supplement.pdf). In cores HU021 and HU085, the dinocyst fluxes are of the order of 50000 and $2000 \mathrm{cysts} / \mathrm{cm}^{2} / \mathrm{ka}$, respectively, which indicate a relatively high productivity at both sites. In core HU021, the assemblages are characterized by the increase of Nematosphaeropsis labyrinthus and temperate taxa from the early to late Holocene. In core HU085, the dinocyst assemblages are dominated by temperate taxa and characterized by maximum of thermophilic species (Spiniferites mirabilis, Impagidinium spp.) in the early Holocene. These dinocyst assemblages are consistent with the more temperate conditions in the axis of the NAC than off the Canadian margins (de Vernal and Hillaire-Marcel, 2006).

PCA performed on dinocyst assemblages show strong linear trends since 8000 cal years BP (Fig. 3b, d). The first eigenvalue $\left(\lambda_{1}\right)$ of the eastern site (HU085) is two times higher than that of the western sites (HU021), which indicate much larger amplitude in the changes of dinocyst assemblages in central North Atlantic than along the Canadian margin. High PCA axis 1 sample scores are driven by the subpolar taxon Spiniferites elongatus in core HU021, whereas they are notably driven by the thermophilic species Spiniferites mirabilis in core HU085 (Supplementary Tables 2c, d, http://www.clim-past.net/5/347/ 2009/cp-5-347-2009-supplement.pdf). As is was observed from the continental records, there is a pronounced change at 


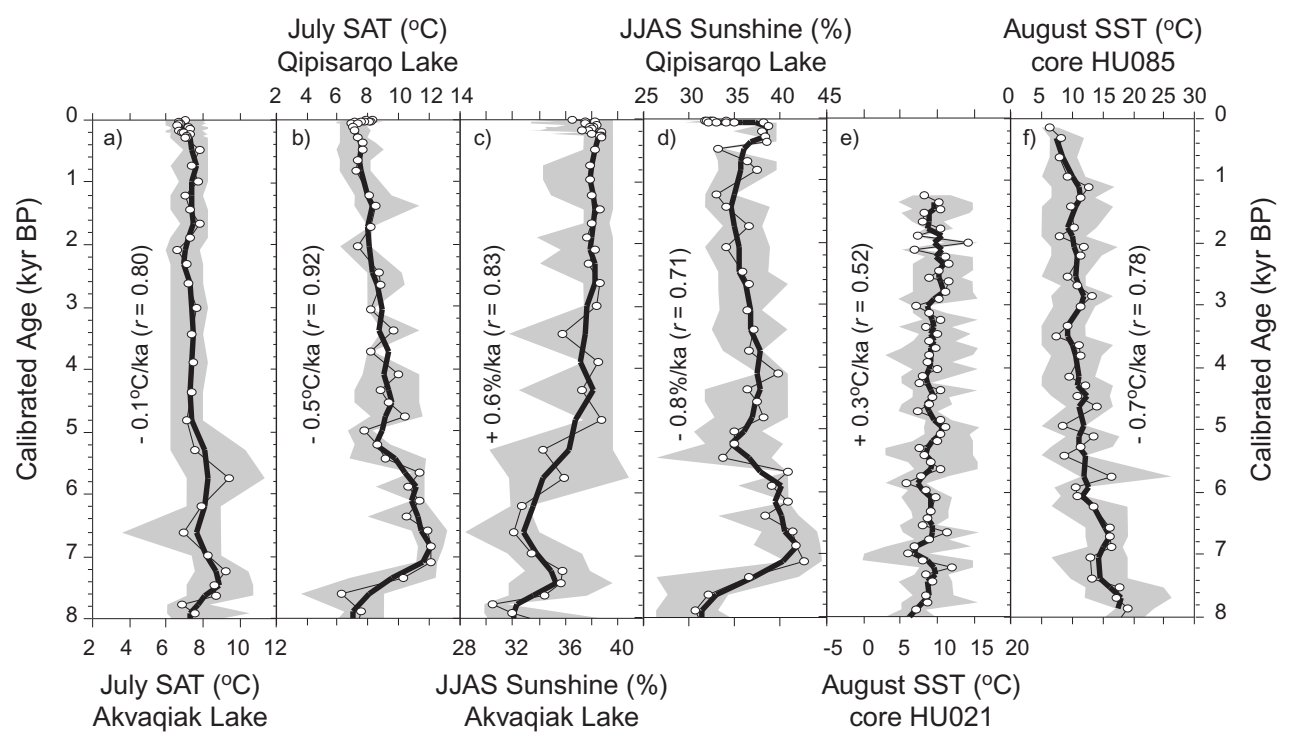

Fig. 4. Time series of climatic and sea-surface conditions. (a) July surface air temperature (SAT) at Akvaqiak Lake. Modern value: $6.2 \pm 1.0^{\circ} \mathrm{C}$ (Environment Canada, 2004). (b) July SAT at Qipisarqo Lake. Modern value: $9.0 \pm 1.1^{\circ} \mathrm{C}$ (Cappelen et al., 2001). (c) Gowing season (JJAS) sunshine at Akvaqiak Lake. Modern value: 39.6 $\pm 5.8 \%$ (New et al., 2002; Whitmore et al., 2005). (d) JJAS sunshine at Qipisarqo Lake. Modern value: 33.2 $\pm 1.9 \%$ (New et al., 2002; Whitmore et al., 2005). (e) August sea-surface temperature (SST) at core HU021 (de Vernal and Hillaire-Marcel, 2006). Modern value: $6.7 \pm 0.9^{\circ} \mathrm{C}$ (NODC, 2001). (f) August SST at core HU085 (de Vernal and Hillaire-Marcel, 2006). Modern value: $10.6 \pm 0.8^{\circ} \mathrm{C}$ (NODC, 2001). On each curve, the thick black lines correspond to 3-point moving averages. Climate trends by millennium since 7000 cal years BP have been calculated from the 3-point moving average curves.

about 5000 cal years BP. Again, the change seems gradual at the western site (HU021), whereas it appears more abrupt at the eastern site (HU085).

Good modern analogues of dinocyst assemblages exist in the modern database, with most dissimilarity values being lower than 23 and 47 in cores HU021 and HU085 respectively, which is much lower than the adopted threshold of 74. August SST was maximum before 5000 cal years BP at the eastern site (HU085), whereas no trend is observed at the western site (HU021). From 7000 cal years BP to present, August SST decreased by $0.7^{\circ} \mathrm{C} / \mathrm{ka}$ at site HU085, whereas a slight warming of $0.3^{\circ} \mathrm{C} / \mathrm{ka}$ is observed at site HU021 (Fig. 4e, f).

\section{Discussion}

\subsection{Mid-Holocene alder occurrence in southwest Greenland}

A feature deserving attention from the pollen record of Qipisarqo Lake is the early occurrence of Alnus crispa, which raised the question of the timing of its migration in southwest Greenland during the Holocene. At present, Alnus crispa has its main area of distribution between $63^{\circ}$ and $66^{\circ} \mathrm{N}$ in west Greenland, with isolated populations growing as far south as $61^{\circ} \mathrm{N}$ (Fredskild, 1973, 1996). Although it is regionally common at $61^{\circ} \mathrm{N}$, shrub alder is not present today in the
Qipisarqo foreland presumably due to the glacier's proximity (less than $2 \mathrm{~km}$ ) (Kaplan et al., 2002).

In the literature, there is a debate regarding Alnus migration in Greenland. Based on pollen studies from southwest Greenland, around $62^{\circ}$ N, Kelly and Funder (1974) proposed an early migration of alder at about 8400 cal years BP (i.e. $7500{ }^{14} \mathrm{C}$ years BP) (Figs. 6, 7e). However, Fredskild $(1973,1983,1985)$ suggested that Alnus rather migrated in west Greenland $\left(64^{\circ} \mathrm{N}\right)$ during the late Holocene between ca. 4500 and 3800 cal years BP (i.e. $4000-3500$ ${ }^{14} \mathrm{C} \mathrm{BP}$ ) (Fig. 7a, b) arguing that Alnus never occupied southern Greenland $\left(<60^{\circ} \mathrm{N}\right)$ (Fig. $\left.7 \mathrm{~g}, \mathrm{~h}, \mathrm{i}\right)$ and that all Alnus pollen grains accumulated in Holocene sediment were related to long distance transport and carried mainly from Newfoundland and Labrador. At Qipisarqo Lake, Alnus pollen relative frequency and fluxes increase at about 8400 cal years BP, to reach maximum values between ca. 7400 and 5600 cal years BP (Fig. 7f).

As shown in Fig. 7, which summarizes available records of pollen influxes over southwestern Greenland during the Holocene, large variations in Alnus frequency from site to site are observed. This may be due to the mosaic character of the local vegetation. Nevertheless, the records strongly suggest time transgressive migration from about 7900 cal years BP in the south (site Isoëtes, ca. $60^{\circ} \mathrm{N}$ ) to about 3800 cal years BP in the north (site Johs. Iversen, ca. $64^{\circ} \mathrm{N}$ ). The distance between the sites is about $600 \mathrm{~km}$. 

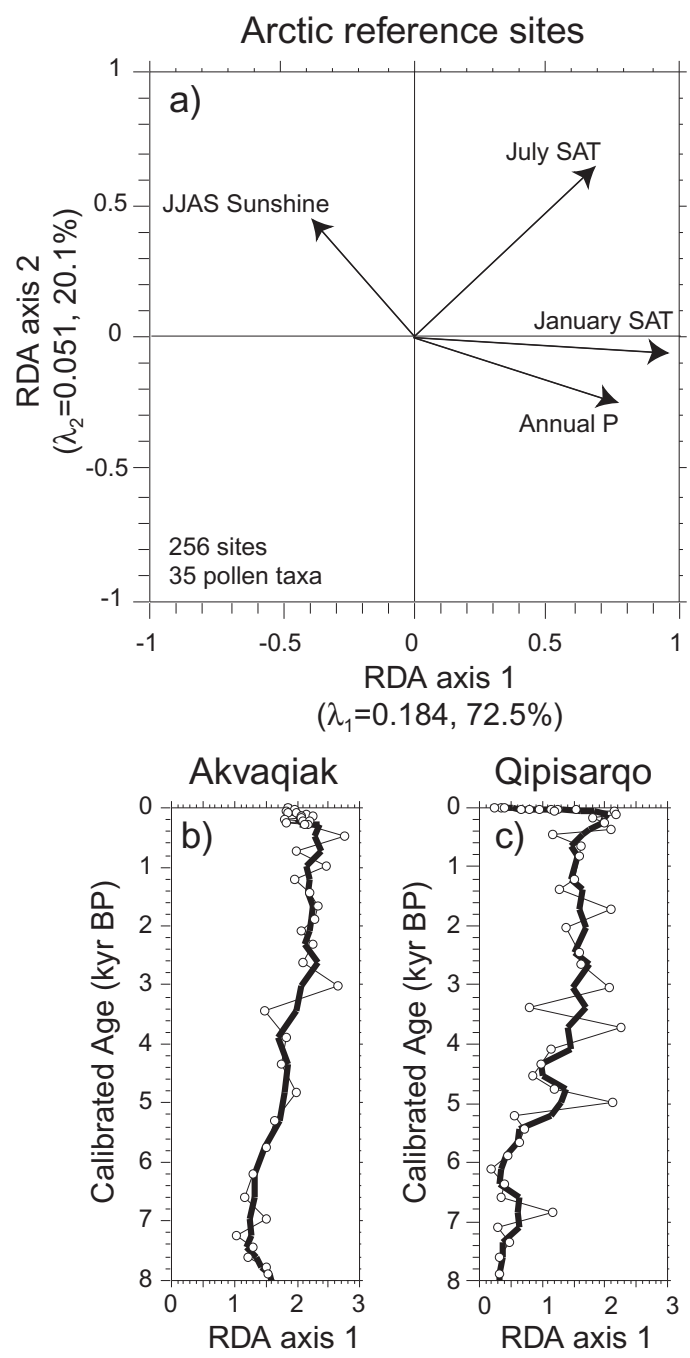

Fig. 5. Results of Redundancy Analysis (RDA). (a) RDA plot of environmental gradients associated with the 256 Arctic reference sites. The eigenvalue $(\lambda)$ and percentage of variance are given for RDA axes 1 and 2. Stratigraphic plot of RDA axis 1 sample scores of (b) Akvaqiak Lake and (c) Qipisarqo Lake. The thick black lines correspond to 3-point moving averages. Informations on RDA summary and loadings are given in Supplementary Table 3 (http: //www.clim-past.net/5/347/2009/cp-5-347-2009-supplement.pdf).

At present, we cannot explain unequivocally the migration of alder in west Greenland nor its absence in south Greenland settings $\left(60^{\circ} \mathrm{N}\right)$. However, we may propose an hypothesis involving the late Holocene sea-level rise in Greenland (e.g. research by Ole Bennike, Geological Survey of Denmark and Greenland, and Antony Long, University of Durham). In the Qaqortoq area $\left(60^{\circ} 40^{\prime} \mathrm{N}, 46^{\circ} \mathrm{W}\right)$, sea level reached its lowest level (ca. 6-8 $\mathrm{m}$ below highest astronomical tide) between 8000 and 6000 cal years BP and the onset of the transgression was at or before 4000 cal years BP, with a local sea level rise until today of $3 \mathrm{~m}$ (Sparrenbom et al., 2006). At

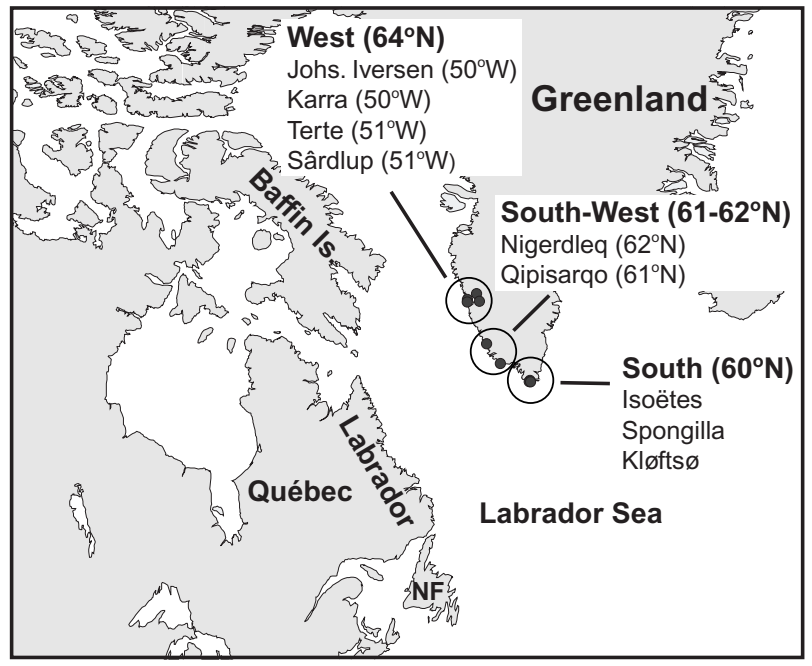

Fig. 6. Location map of southwestern Greenland pollen sites.

southern Greenland sites (ca. $60^{\circ} \mathrm{N}, 44^{\circ} \mathrm{W}$ ) and at Qipisarqo Lake $\left(61^{\circ} \mathrm{N}, 47^{\circ} \mathrm{W}\right)$, Alnus influx was maximum between 8000 and 4000 cal years BP and decreased afterward (Fig. 7). In the Qaqortoq area, one consequence of this transgression is that late Holocene settlements of Paleo-Eskimo cultures may have been transgressed by the sea (Sparrenbom et al., 2006). Because Alnus crispa prefers inland settings (Fredskild, 1996), we propose that the late Holocene sea-level rise might have caused its disappearance from south Greenland and its migration in west Greenland. However, other studies are needed for a clear demonstration.

\subsection{West to east gradient}

At all sites there is a pronounced palynological change around the mid-late Holocene transition, at about 5000 cal years BP (Fig. 3). The change seems abrupt in the dinocyst and pollen records of eastern sites (HU085 and Qipisarqo), whereas it appears more gradual westward (HU021 and Akvaqiak). An abrupt mid to late Holocene transition has been also reported from coccolith and dinocyst data in marine cores from the central North Atlantic, south of Iceland (Giraudeau et al., 2000) and on the northern Iceland shelf (Solignac et al., 2006). It seems therefore to be a robust feature in the regional and global climate (e.g. Steig, 1999).

The records of Akvaqiak and Qipisarqo lakes show a progressive decrease in July SAT since 7000 cal years BP. However, the cooling at Qipisarqo is about $3.5^{\circ} \mathrm{C}$, which is much larger than at Akvaqiak, where it does not exceed $1^{\circ} \mathrm{C}$ (Fig. 8a). Similarly, the marine records show a progressive decrease in August SST of about $5^{\circ} \mathrm{C}$ in the central North Atlantic site (HU085), whereas no significant trend is observed at the Canadian margin site (HU021; Fig. 8b). West to 


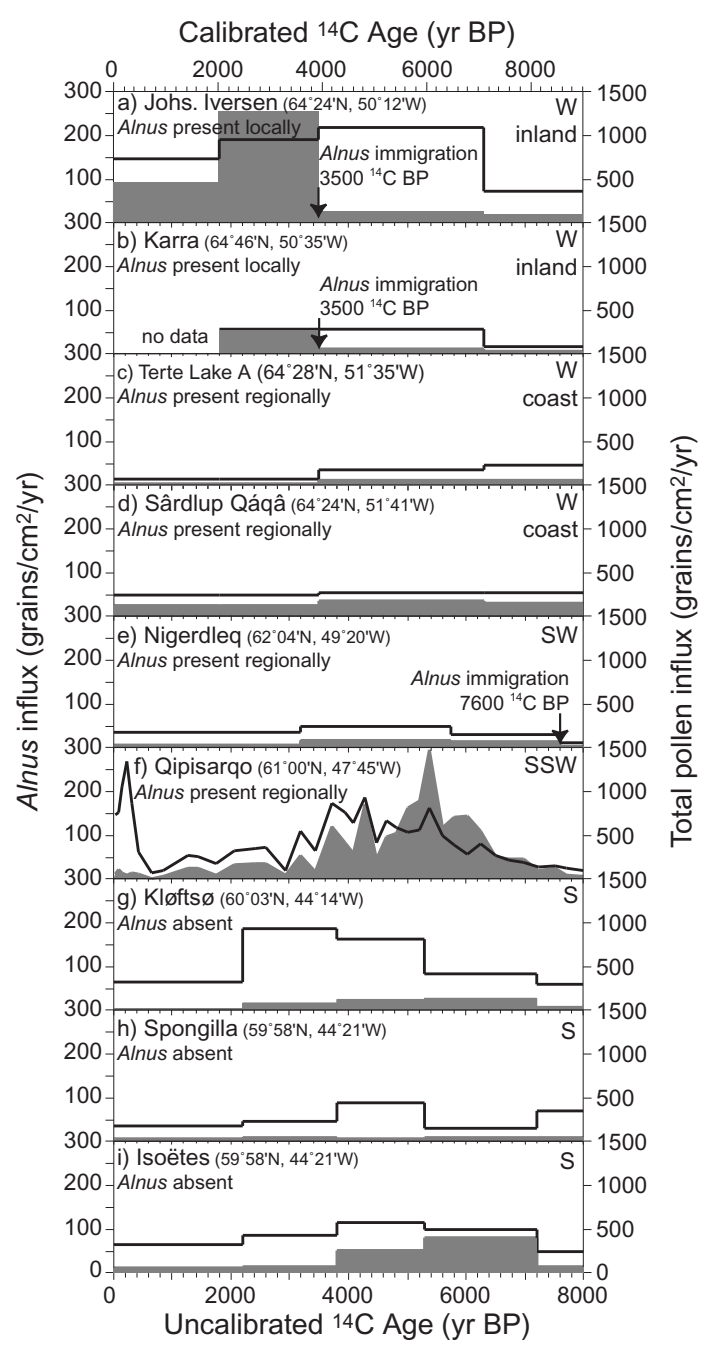

Fig. 7. Mid-late Holocene Alnus and total pollen influxes of southwestern Greenland sites (cf. Fig. 6). The results are presented against uncalibrated and calibrated radiocarbon ages. The influx values given by Fredskild (1973, 1983), and Kelly and Funder (1974) were calculated with uncalibrated radiocarbon dates. Therefore, the influx values at Qipisarqo Lake presented here were also estimated following an age-depth model constructed with uncalibrated radiocarbon dates. (a-d) Data from west Greenland sites (Fredskild, 1983). (e) Data from south-west Greenland site (Kelly and Funder, 1974). (g-i) Data from south Greenland sites (Fredskild, 1973). The influxes were calculated by Fredskild (1973, 1983) and Kelly and Funder (1974) and presented as average for each pollen assemblage zones. (f) Data from Qipisarqo Lake (this study). At present, Alnus crispa grows only around (a) Johs. Iversen and (b) Karra sites. On each graph, the shaded curve corresponds to Alnus pollen influx and the thick black line corresponds to total pollen influx. The total pollen influx includes Alnus pollen grains but excludes long-distance pollen grains from trees, Ambrosia and Chenopodiaceae. High Alnus percentages $(>20 \%)$ are recorded only at (a) Johs. Iversen and (f) Qipisarqo sites. At these sites, the Alnus pollen influx overlaps the total pollen influx at some levels. east gradient in the amplitude of the Holocene cooling trend seems to be a consistent feature across the mid- to high latitude North Atlantic (e.g. Andersen et al., 2004; de Vernal and Hillaire-Marcel, 2006).

The difference between the eastern and western sites is also seen in the growing season sunshine reconstruction from pollen data. The record of Akvaqiak Lake shows a slight increase since 7000 cal years BP, whereas a progressive decrease is reconstructed at Qipisarqo Lake (Fig. 8c). Independent evidence for changes in growing season sunshine comes from pollen fluxes (grains $/ \mathrm{cm}^{2} / \mathrm{yr}$ ), which relate to pollen production and positively correlate with meteorological factors such as daily thermal oscillation, maximum and minimum temperatures and sunshine hours (cf. RodríguezRajo et al., 2005). Since 7000 cal years BP, pollen fluxes have decreased at Qipisarqo while they display an increase at Akvaqiak (Fig. 8d), thus supporting the growing season sunshine reconstruction based on transfer functions. The trend in pollen fluxes provides an illustration of the response of Arctic plants to changes in climate parameters such as sunshine (Fréchette et al., 2008b).

\subsection{Linkage between atmospheric circulation and sur- face ocean currents}

Our reconstructions show summer cooling trend since 7000 calyears BP particularly pronounced in southern Greenland. They also indicate a slight winter warming from the mid to late Holocene (Fig. 8e), which suggests a decrease in the seasonal contrast of temperatures from winter to summer. Such an interpretation in terms of seasonality that applies to both terrestrial and marine environments is supported by paleoecological data from Scandinavia (e.g. Hammarlund et al., 2002) and paleoceanographic records from the northern North Atlantic (de Vernal and Hillaire-Marcel, 2006; Solignac et al., 2006). It appears consistent with mid-late Holocene summer vs. winter insolation changes (Fig. 8f) (Berger and Loutre, 1991).

The mid to late Holocene insolation change certainly accounts for a large part in the cooling recorded and the decreasing winter to summer contrast of temperature. However, the amplitude of the cooling is much smaller in the western North Atlantic than in the eastern North Atlantic and most probably reflect changes in the ocean circulation pattern. Particularly strong west to east thermal gradient during the mid Holocene may have been related to stronger and/or warmer NAC which resulted in enhanced poleward heat fluxes in eastern North Atlantic and Nordic Seas (e.g. Duplessy et al., 2001; Birks and Koç, 2002). Conversely, high freshwater and meltwater export from the Arctic through BLC and LC may have maintained cold conditions along the continental margins of the western North Atlantic during the early and mid Holocene despite higher insolation (e.g. de Vernal and Hillaire-Marcel, 2006). An accelerated hydrographical cycle with higher northward flux of warm Atlantic waters to 


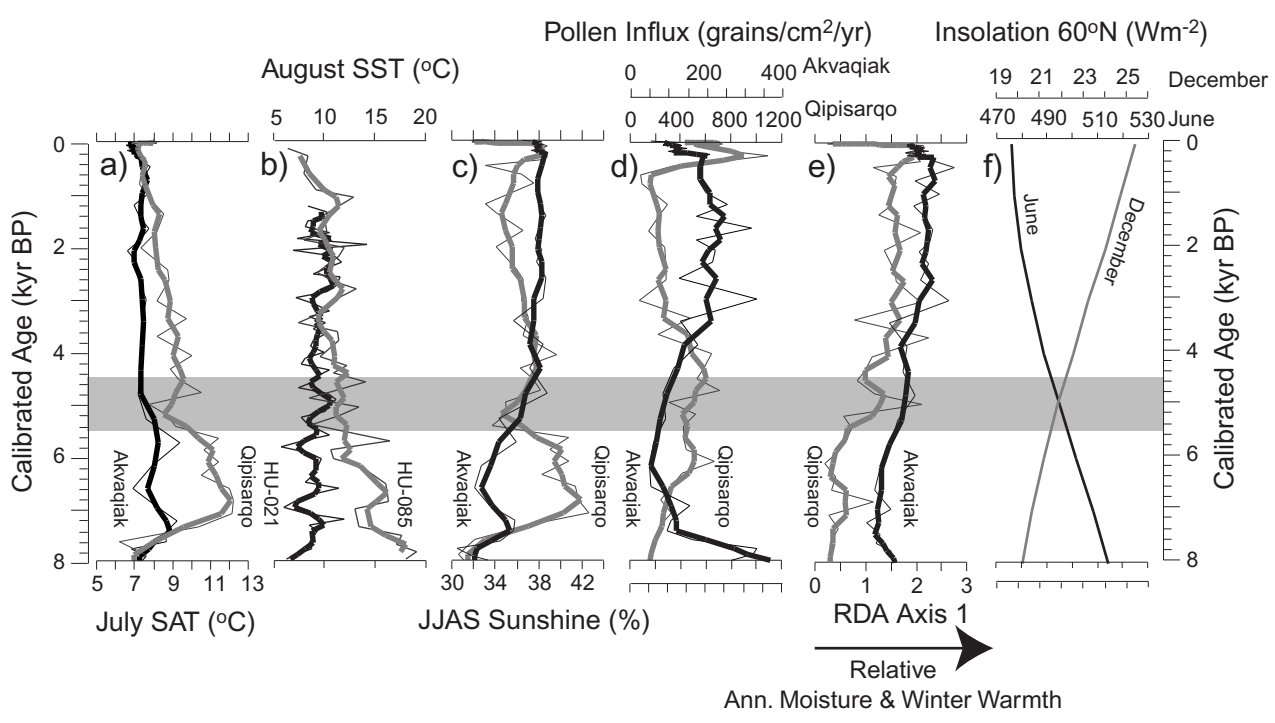

Fig. 8. Contrasting trend in climatic and sea-surface conditions. (a) July SAT reconstruction at Akvaqiak (black) and Qipisarqo (grey) lakes. (b) August SST reconstruction from cores HU021 (black) and HU085 (grey) (de Vernal and Hillaire-Marcel, 2006). (c) JJAS sunshine reconstruction at Akvaqiak (black) and Qipisarqo (grey) lakes. (d) Total pollen influx at Akvaqiak (black) and Qipisarqo (grey) lakes. (e) Stratigraphic plot of RDA axis 1 scores at Akvaqiak (black) and Qipisarqo (grey) lakes. This curve represents an estimation of the January air temperature and annual precipitation trends, which are co-variant parameters (Supplementary Tables 3 and 4, http://www.clim-past.net/ 5/347/2009/cp-5-347-2009-supplement.pdf). (f) Northern Hemisphere high-latitude $\left(60^{\circ} \mathrm{N}\right)$ June and December insolation curves (Berger and Loutre, 1991). On figures (a-e) the thick lines correspond to 3-point moving averages. The shaded horizontal zone marks the mid-late Holocene transition, which occurred at ca. 5000 cal years BP.

the east and higher southward export of Arctic waters to the west in the northern North Atlantic thus seem to have characterized the middle Holocene. On these bases, relationships with positive NAO-like synoptic patterns can be proposed (e.g. Hurrell and Dickson, 2004). Indeed, during the positive phase of the NAO, the eastward wind speed is high and the northeastward flow of the NAC appears stronger than during the negative phase of the NAO, which results in SST higher in the route of the NAC (e.g. Flatau et al., 2003).

Positive phases of the NAO are presently characterized by reduced strength and frequency of cyclonic activity in the Labrador Sea (Serreze et al., 1997), which result in overall decrease in cloudiness over much of the North Atlantic, west of Greenland (Previdi and Veron, 2007), possibly in relationship to sea-ice cover. There are indeed some studies documenting more extended sea ice in the Labrador Sea under positive NAO (e.g. Drinkwater, 2004; Heide-Jørgensen et al., 2007). The increasing trend of cloud cover in southern Greenland might thus be related to long-term changes in synoptic scale atmospheric circulation patterns, with a progressive shift from dominant NAO+ in the mid Holocene (e.g. Gladstone et al., 2005; Davis and Stevenson, 2007) to negative NAO in the late Holocene.

\section{Conclusions}

Our terrestrial climate reconstructions and the paleoceanographical records from northwest North Atlantic region illustrate the sensitivity of the climate system during a warm interglacial interval and evidence strong linkages between terrestrial climate, oceanic surface conditions and synoptic scale atmospheric circulation patterns in the subpolar North Atlantic during the mid to late Holocene. The present study also provides an illustration of the response of Arctic plants to the North Atlantic Oscillation (Mysterud et al., 2003).

Acknowledgements. This study is a contribution of the Polar Climate Stability Network (PCSN) supported by the Canadian Foundation of Climate and Atmospheric Science (CFCAS). We also acknowledge financial support from the Natural Sciences and Engineering Research Council (NSERC) of Canada and the Fonds Québécois de Recherche sur les sciences de la Nature et les Technologies (FQRNT). We are grateful to Gifford H. Miller and Alexander P. Wolfe for the access to core samples. We are also grateful to Denis Didier Rousseau, Pierre J. H. Richard and to the two anonymous journal referees for their constructive comments on the manuscript. This is GEOTOP Publication No. 2009-0013.

Edited by: D.-D. Rousseau 


\section{References}

Andersen, C., Koç, N., Jennings, A., and Andrews, J. T.: Non uniform response of the major surface currents in the Nordic Seas to insolation forcing: implications for the Holocene climate variability, Paleoceanography, 19, PA2003, doi:10.1029/2002PA000873, 2004.

Anderson, P. M., Bartlein, P. J., Brubaker, L. B., Gajewski, K., and Ritchie, J. C.: Modern analogues of late-Quaternary pollen spectra from the western interior of North America, J. Biogeogr., 16, 573-596, 1989.

Berger, A. and Loutre, M. F.: Insolation values for the climate of the last 10 million years, Quat. Sci. Rev., 10, 297-318, 1991.

Birks, C. J. A. and Koç, N.: A high-resolution diatom record of lateQuaternary sea-surface temperatures and oceanographic conditions from the eastern Norwegian Sea, Boreas, 31, 323-344, 2002.

Birks, H. J. B.: Modern pollen rain and vegetation of the St. Elias Mountains, Yukon Territory, Can. J. Bot., 55, 2367-2382, 1977.

Birks, H. J. B.: Quantitative palaeoenvironmental reconstructions, in Statistical Modelling of Quaternary Science Data, Technical guide 5, Quaternary Research Association, edited by: Maddy D. and Brew, J. S, Cambridge, 161-254, 1995.

Cappelen, J., Jørgensen, B., Laursen, E., Stanius, L., and Thomsen, R.: The observed climate of Greenland 1958-99 - with climatological normals, 1961-90, Danish Meteorological Institute, Technical Report No. 00-18, Copenhagen, 149 pp., 2001.

Chen, Q. S, Bromwich, D. H., and Bai, L.: Precipitation over Greenland retrieved by a dynamic method and its relation to cyclonic activity, J. Clim., 10, 839-870, 1997

Davis, B. S. A. and Stevenson, A. C.: The 8.2 ka event and EarlyMid Holocene forests, fires and floodings in the Central Ebro Desert, NE Spain, Quat. Sci. Rev., 26, 1695-1712, 2007.

de Vernal, A., Henry, M., Matthiessen, J., Mudie, P.J., Rochon, A., Boessenkool, K. P., Eynard, F., Grøsfjeld, K., Guiot, J., Hamel, D., Harland, R., Head, M.J., Kunz-Pirrung, M., Levac, E., Loucheur, V., Peyron, O., Pospelova, V., Radi, T., Turon, J. L., and Voronina, E.: Dinocyst assemblages as tracers of seasurface conditions in the northern North Atlantic, Arctic and subArctic seas: the new ' $n=677$ ' data base and its application for quantitative palaeoceanographic reconstruction, J. Quat. Sci., 16, 681-698, 2001.

de Vernal, A., Eynaud, F., Henry, M., Hillaire-Marcel, C., Londeix, L., Mangin, S., Matthiessen, J., Marret, F., Radi, T., Rochon, A., Solignac, S. and Turon, J. L.: Reconstruction of sea-surface conditions at middle to high latitudes of the Northern Hemisphere during the Last Glacial Maximum (LGM) based on dinocyst assemblages, Quat. Sci. Rev., 24, 897-924, 2005.

de Vernal, A. and Hillaire-Marcel, C.: Provincialism in trends and high frequency changes in the northwestern North Atlantic during the Holocene, Global Planet. Changes, 54, 263-290, 2006.

Drinkwater, K. F.: Atmospheric and sea-ice conditions in the Northwest Atlantic during the decade, 1991-2000, J. Northw. Atl. Fish. Sci., 34, 1-11, 2004.

Duplessy, J. C., Ivanova, E., Murdmaa, I., Paterne, M., and Labeyrie, L.: Holocene paleoceanography of the northern Barents Sea and variations of the northward heat transport by the Atlantic Ocean, Boreas, 30, 2-16, 2001.

Environment Canada: Canadian Climate Normals, http://climate. weatheroffice.ec.gc.ca/climate_normals/index_e.html, 2004.
Faegri, K. and Iversen, J.: Textbook of Pollen Analysis, 3rd Edition, Hafner Press, New York, 295 pp., 1975.

Flatau, M. K., Talley, L., and Niiler, P. P.: The North Atlantic Oscillation, surface current velocities, and SST changes in the subpolar North Atlantic, J. Clim., 16, 2355-2369, 2003.

Fréchette, B., de Vernal, A., Guiot, J., Wolfe, A. P., Miller, G. H., Fredskild, B., Kerwin, M. K., and Richard, P. J. H.: Methodological basis for quantitative reconstruction of air temperrature and sunshine from pollen assemblages in Arctic Canada and Greenland, Quat. Sci. Rev., 27, 1197-1216, 2008a.

Fréchette, B., de Vernal, A., and Richard, P. J. H.: Holocene and Last Interglacial cloudiness in eastern Baffin Island, Arctic Canada, Can. J. Earth Sci., 45, 1221-1234, 2008 b.

Fredskild, B.: Studies in the vegetational history of Greenland. Palaeobotanical investigations of some Holocene lake and bog deposits, Meddr Grønland, 198, 245 pp., 1973.

Fredskild, B.: The Holocene vegetational development of the Godhåbsfjord area, West Greenland, Meddr Grønland, Geosci., 10, 28 pp., 1983.

Fredskild, B.: Holocene pollen records from west Greenland, in: Quaternary environments: Eastern Canadian Arctic, Baffin Bay and Western Greenland, edited by: Andrews, J. T., Allen and Unwin, Boston, 643-681, 1985.

Fredskild, B.: The genus Betula in Greenland - Holocene history, present distribution and synecology, Nordic J. Bot., 11, 393-412, 1991.

Fredskild, B.: A phytogeographical study of the vascular plants of West Greenland $\left(62^{\circ} 20^{\prime}-74^{\circ} 00^{\prime}\right)$, Meddr Grønland, Biosci., 45, 157 pp., 1996.

Gauch Jr., H. G.: Multivariate analysis in community ecology, Cambridge University Press, Cambridge, 298 pp., 1982.

Gavin, D. G., Oswald, W. W., Wahl, E. R., and Williams, J. W.: A statistical approach to evaluating distance metrics and analog assignments for pollen records, Quat. Res., 60, 356-367, 2003.

Giraudeau, J., Cremer, M., Manthé, S., Labeyrie, L., and Bond, G.: Coccolith evidence for instabilities in surface circulation south of Iceland during Holocene times, Earth Planet. Sci. Lett., 179, 257-268, 2000.

Gladstone, R. M., Ross,I., Valdes, P. J., Abe-Ouchi, A., Braconnot, P., Brewer, S., Kageyama, M., Kitoh, A., Legrande, A., Marti, O., Ohgaito, R., Otto-Bliesner, B., Peltier, W. R., and Vettoretti, G.: Mid-Holocene NAO: A PMIP2 model intercomparison, Geophys. Res. Lett., 32, L16707, doi:10.1029/2005GL023596, 2005.

Guiot, J. and Goeury, G.: 3Pbase - a software for statistical analysis of paleoecological and paleoclimatological data, Dendrochronologia, 14, 123-135, 1996.

Hammarlund, D., Barnekow, L., Birks, H. J. B., Buchardt, B., and Edwards, T. W. D.: Holocene changes in atmospheric circulation recorded in the oxygen-isotope stratigraphy of lacustrine carbonates from northern Sweden, Holocene, 12, 339-351, 2002.

Heide-Jørgensen, M. P., Stern, H., and Laidre, K. L.: Dynamics of the sea ice edge in Davis Strait, J. Marine Syst., 67, 170-178, 2007.

Hughen, K. A., Baillie, M. G. L., Bard, E., Bayliss, A., Beck, J. W., Bertrand, C., Blackwell, P. G., Buck, C. E., Burr, G., Cutler, K. B., Damon, P. E., Edwards, R. L., Fairbanks R. G., Friedrich, M., Guilderson, T. P., Kromer, B., McCormac, F. G., Manning, S., Bronk Ramsey, C., Reimer, P. J., Reimer, R. W., Remmele, S., Southon, J. R., Stuiver, M., Talamo, S., Taylor, F. M., van 
der Plicht, J., and Weyhenmeyer C. E.: Marine04 Marine Radiocarbon Age Calibration, 0-26 cal. kyr BP, Radiocarbon, 46, 1059-1086, 2004.

Hurrell, J. W.: Decadal trends in the North Atlantic Oscillation: Regional temperatures and precipitation, Science, 269, 676-679, 1995.

Hurrell, J. W. and Dickson, R. R.: Climate variability over the North Atlantic, in: Marine Ecosystems and Climate Variation - the North Atlantic, edited by: Stenseth, N. C., Ottersen, G., Hurrell, J. W., and Belgrano, X., Oxford University Press, New York, 15-31, 2004.

Kaplan, M. R., Wolfe, A. P., and Miller, G. H.: Holocene environmental variability in southwestern Greenland inferred from lake sediments, Quat. Res., 58, 149-159, 2002.

Kaufman, D. K., Ager, T. A., Anderson, N. J., Anderson, P. M., Andrews, J. T., Bartlein, P. J., Brubaker, L. B., Coats, L. L., Cwynar, L. C., Duvall, M. L., Dyke, A. S., Edwards, M. R., Eisner, W. R., Gajewski, K., Geirsdottir, A., Hu, F. S., Jennings, A. E., Kaplan, M. R., Kerwin, M. W., Lozhkin, A. V., MacDonald, G. M., Miller, G. H., Mock, C. J., Oswald, W. W., Otto-Bliesner, B. L., Porinchu, D. F., Ruhland, K., Smol, J. P., Steig, E. J., and Wolfe, B. B.: Holocene thermal maximum in the western Arctic (0-180 W), Quat. Sci. Rev., 23, 529-560, 2004.

Kelly, M. and Funder, S.: The pollen stratigraphy of late Quaternary lake sediments of South-West Greenland, Rapp. Grønlands Geol. Unders., 64, 1-26, 1974.

Legendre, P. and Legendre, L.: Numerical ecology, 2nd English edition, Elsevier Science BV, Amsterdam, 853 pp., 1998.

Marchal, O., Cacho, I., Stocker, T. F., Grimalt, J. O., Calvo, E., Martrat, B., Shackelton, N., Vautravers, M., Cortijo, E., Van Kreveld, S., Andersson, C., Koç, N., Chapman, M., Sbaffi, L., Duplessy, J. C., Sarnthein, M., Turon, J. L., Duprat, J., and Jansen, E.: Apparent cooling of the sea surface in the northeast Atlantic and Mediterranean during the Holocene, Quat. Sci. Rev., 21, 455483, 2002.

McAndrews, J. H., Berti, A. A., and Norris, G.: Key to the Quaternary pollen and spores of the great Lakes region, Life Science Miscellaneous Publications, Royal Ontario Museum, Toronto, Canada, 64 pp., 1973.

Moore, P. D., Webb, J. A., and Collinson, M. E.: Pollen analysis, 2nd edition, Blackwell Scientific Publications, Oxford, 216 pp., 1991.

Moros, M., Emeis, K., Risebrobakken, B., Snowball, I., Kuijpers, A., McManus, J., and Jansen, E.: Sea surface temperatures and ice rafting in the Holocene North Atlantic: climate infuences on northern Europe and Greenland, Quat. Sci. Rev., 23, 2113-2126, 2004.

Mysterud, A., Stenseth, N. C., Yoccoz, N. G., Ottersen, G. O., and Langvatn, R.: The response of terrestrial ecosystems to climate variability associated with the North Atlantic Oscillation, in: The North Atlantic Oscillation, Climatic Significance and Environmental Impact, Geophys. Monogr. Ser., vol. 134, edited by: Hurrell, J. W., Kushnir, Y., Ottersen, G., and Visbeck,M., AGU, Washington, D.C, 235-262, 2003.

New, M., Hulme, M., and Jones, P.: Representing twentieth-century space-time climate variability. Part I: Development of a 196190 mean monthly terrestrial climatology, J. Clim., 12, 829-856, 1999.

New, M., Lister, D., Hulme, M., and Makin, I.: A high-resolution data set of surface climate over global land areas, Clim. Res., 21, 1-25, 2002.

NODC: World Ocean Database 2001, Scientific Data Sets, Observed and Standard Level Oceanographic Data [CD-Rom], Natl. Oceanogr. Data Cent., Silver Spring, Md, 2001.

Overpeck, J. T., Webb III, T., and Prentice, I.C.: Quatitative interpretation of fossil pollen spectra: dissimilarity coefficients and the method of modern analogs, Quat. Res., 23, 87-108, 1985.

Prentice, I. C.: Multidimensional scaling as a research tool in Quaternary palynology: a review of theory and methods, Rev. Palaeobot. Palynol., 31, 71-104, 1980.

Previdi, M. and Veron, D. E.: North Atlantic cloud cover response to the North Atlantic oscillation and relationship to surface temperature changes, J. Geophys. Res., 112, D07104, doi:10.1029/2006JD007516, 2007.

Reimer, P. J., Baillie, M. G. L., Bard, E., Bayliss, A., Beck, J. W., Bertrand, C. J. H., Blackwell, P. G., Buck, C. E., Burr, G. S., Cutler, K. B., Damon, P. E., Edwards, R. L., Fairbanks, R. G., Friedrich, M., Guilderson, T. P., Hogg, A. G., Hughen, K. A., Kromer, B., McCormac, F. G., Manning, S. W., Ramsey, C. B., Reimer, R. W., Remmele, S., Southon, J. R., Stuiver, M., Talamo, S., Taylor, F. W., van der Plicht, J., and Weyhenmeyer, C. E.: IntCal04 Terrestrial radiocarbon age calibration, 26-0 ka BP, Radiocarbon, 46, 1029-1058, 2004.

Renssen, H., Goose, H., Fichefet, T., Brovkin, V., Driesschaert, E., and Wolk, F.: Simulating the Holocene climate evolution at northern high latitudes using a coupled atmospheric-sea iceocean-vegetation model, Clim. Dyn., 24, 23-43, 2005.

Richard, P. J. H.:Atlas pollinique des arbres et de quelques arbustes indigènes du Québec, Nat. Can., 97, 1-34, 97-161, 241-306, 1970.

Rodríguez-Rajo, F. J., Méndez, J., and Jato, V.: Factors affecting pollination ecology of Quercus anemophilous species in northwest Spain, Bot. J. Linnean Soc., 149, 283-297, 2005.

Rousseau, D. D., Schevin, P., Ferrier, J., Jolly, D., Andreasen, T., Ascanius, S. E., Hendriksen, S. E., and Poulsen, U.: Long-distance pollen transport from North America to Greenland in spring, J. Geophys. Res., 113, G02013, doi:10.1029/2007JG000456, 2008.

Serreze, M. C., Carse, F., Barry, R. G., and Rogers, J. C.: Icelandic Low cyclone activity: Climatological features, linkages with the NAO, and relationship with recent changes in the Northern Hemisphere circulation, J. Clim., 10, 453-464, 1997.

Solignac, S., Giraudeau, J., and de Vernal, A.: Holocene sea surface conditions in the western North Atlantic: Spatial and temporal heterogeneities, Paleoceanography, 21, PA2004, doi:10.1029/2005PA001175, 2006.

Sparrenbom, C. J., Bennike, O., Björck, S., and Lambeck, K.: Holocene relative sea-level changes in the Qaqortoq area, southern Greenland, Boreas, 35, 171-187, 2006.

Steig, E. J.: Mid-Holocene climate change, Science, 286, 1485 1487, 1999.

Stuiver, M. and Reimer, P. J.: Extended 14C database and revised CALIB radiocarbon calibration program, Radiocarbon, 35, 215 230, 1993.

ter Braak, C. J. F and Prentice, I. C.: A theory of gradient analysis, Adv. Ecol. Res., 18, 271-317, 1988.

ter Braak, C. J. F., and Šmilauer, P.: CANOCO for windows: software for Canonical Community Ordination (version 4), Micro- 
computer Power, Ithaca, NY, USA, 1998.

Tsukernik, M., Kindig, D. N., and Serreze, M. C.: Characteristics of winter cyclone activity in the northern North Atlantic: Insights from observations and regional modeling, J. Geophys. Res., 112, D03101, doi:10.1029/2006JD007184, 2007.

Whitmore, J., Gajewski, K., Sawada, M., Williams, J. W., Shuman, B., Bartlein, P. J., Minckley, T., Viau, A.E., Webb III, T., Shafer, S., Anderson, P., and Brubaker, L.: Modern pollen data from North America and Greenland for multi-scale paleoenvironmental applications, Quat. Sci. Rev., 24, 1828-1848, 2005.

Wohlfahrt, J., Harrison, S.P., and Braconnot, P.: Synergistic feedbacks between ocean and vegetation on mid- and high-latitude climates during the mid-Holocene, Clim. Dyn., 22, 223-238, 2004. 